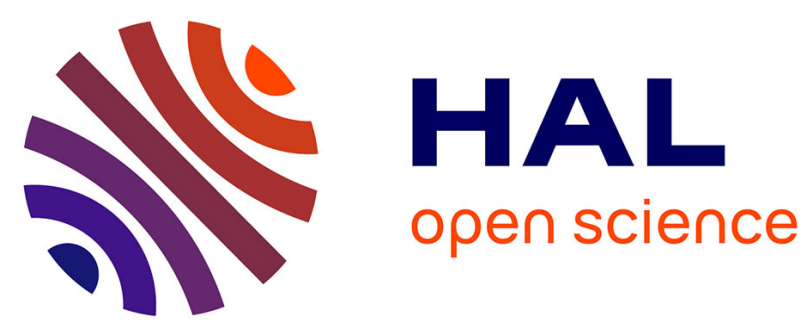

\title{
Last glacial fire regime variability in western France inferred from microcharcoal preserved in core MD04-2845, Bay of Biscay
}

\author{
Anne-Laure Daniau, Maria Fernanda Sánchez Goñi, Josette Duprat
}

\section{To cite this version:}

Anne-Laure Daniau, Maria Fernanda Sánchez Goñi, Josette Duprat. Last glacial fire regime variability in western France inferred from microcharcoal preserved in core MD04-2845, Bay of Biscay. Quaternary Research, 2009, 71 (3), pp.385-396. 10.1016/j.yqres.2009.01.007 . hal-03210043

\section{HAL Id: hal-03210043 \\ https://hal.science/hal-03210043}

Submitted on 27 Apr 2021

HAL is a multi-disciplinary open access archive for the deposit and dissemination of scientific research documents, whether they are published or not. The documents may come from teaching and research institutions in France or abroad, or from public or private research centers.
L'archive ouverte pluridisciplinaire HAL, est destinée au dépôt et à la diffusion de documents scientifiques de niveau recherche, publiés ou non, émanant des établissements d'enseignement et de recherche français ou étrangers, des laboratoires publics ou privés. 


\title{
Last glacial fire regime variability in western France inferred from microcharcoal preserved in core MD04-2845, Bay of Biscay
}

\author{
Anne-Laure Daniau ${ }^{\mathrm{a}, \mathrm{b}, *}$, Maria Fernanda Sánchez Goñi ${ }^{\mathrm{a}}$, Josette Duprat ${ }^{\mathrm{a}}$ \\ a Université de Bordeaux1, EPHE, CNRS UMR5805, EPOC, bât B18, Avenue des Facultés, 33405 TALENCE Cedex, France \\ b Université de Bordeaux1, CNRS UMR5199 PACEA, Institut de Préhistoire et Géologie du Quaternaire, bât B18, Avenue des Facultés, 33405 TALENCE Cedex, France
}

\section{A R T I C L E I N F O}

Article history:

Received 17 January 2008

Available online $\mathrm{xxxx}$

\section{Keywords:}

Marine sequence

Charcoal

Biomass burning

France

Dansgaard-Oeschger events

Heinrich events

\begin{abstract}
A B S T R A C T
High resolution multiproxy analysis (microcharcoal, pollen, organic carbon, Neogloboquadrina pachyderma (s), ice rafted debris) of the deep-sea record MD04-2845 (Bay of Biscay) provides new insights for understanding mechanisms of fire regime variability of the last glacial period in western France. Fire regime of western France closely follows Dansgaard-Oeschger climatic variability and presents the same pattern than that of southwestern Iberia, namely low fire regime associated with open vegetation during stadials including Heinrich events, and high fire regime associated with open forest during interstadials. This supports a regional climatic control on fire regime for western Europe through fuel availability for the last glacial period. Additionally, each of Heinrich events 6, 5 and 4 is characterised by three episodes of fire regime, with a high regime bracketed by lower fire regime episodes, related to vegetational succession and complex environmental condition changes.
\end{abstract}

(c) 2009 University of Washington. All rights reserved.

\section{Introduction}

Beyond man-made fires, biomass burning depends on climate and also appears to be a significant driver for climate change through the release of greenhouse gases, namely carbon dioxide, methane, nitric oxide and aerosols (Crutzen et al., 1979; Lobert et al., 1990; Andreae and Merlet, 2001; van Aardenne et al., 2001; Van der Werf et al., 2004; Thonicke et al., 2005). Variations of atmospheric greenhouse gas concentration in concert with the millenial-scale Dansgaard-Oeschger (D-O) climatic variability have been identified in Greenland and Antarctic ice cores (Petit et al., 1999; Flückiger et al., 2004). However, the influence of fire regime (fire intensity, severity, size, frequency at regional and centuries time-scale following Hu et al., 2006) on these variations is poorly understood due to the lack of high-resolution fire regime records covering this period. A recent synthesis of charcoal records covering the last $21 \mathrm{ka}$ (Power et al., 2007) shows that spatial fire regime variations were not constant through this time related to changes of climate and local fuel load. High resolution deep-sea microcharcoal records covering the last glacial period (LGP) can provide new perspectives for understanding mechanisms of fire regime variability such as vegetation type, amount of fuel, climate changes through periods of drought, lightning storm position, human activity or orbital forcing.

\footnotetext{
* Corresponding author. Université de Bordeaux1, CNRS UMR5199 PACEA, Institut de Préhistoire et Géologie du Quaternaire, bât B18, Avenue des Facultés, 33405 TALENCE Cedex, France. Fax: +33 540008451 .

E-mail addresses: al.daniau@ipgq.u-bordeaux1.fr (A.-L. Daniau), mf.sanchezgoni@epoc.u-bordeaux1.fr (M.F.S. Goñi), jm.duprat@orange.fr (J. Duprat).
}

The impact of D-O climatic variability on fire regime was detected 45 for the first time in southwestern Iberia (Daniau et al., 2007), a region 46 that experiences at present a frequent fire activity. The Iberian fire 47 regime variability has been related to changes of fuel amount through 48 shifts in vegetation between Greenland stadials (GS) including 49 Heinrich events (HE), which experienced low fire regime associated 50 with semi-desert vegetation, and Greenland interstadials (GI), which 51 experienced high fire regime associated with open Mediterranean 52 forest and heathland development. Changes in moisture and tem- 53 perature conditions determine the type of vegetation, which in turn 54 controls the amount of fuel and the fire return interval.

Fire regime and vegetation shift registered in southwestern Iberia 56 between GS and GI have been related to prevailing atmospheric 57 situations similar to the present-day positive and negative North 58 Atlantic Oscillation (NAO) index, respectively (Daniau et al., 2007). The 59 NAO is one of the major mechanisms responsible for the present-day 60 wintertime temperature and precipitation patterns across the North 61 Atlantic region. During the positive phase of NAO, the Mediterranean 62 region experiences major drought because of the shift of the 63 westerlies northwards, whereas a negative phase brings humidity to 64 this region due to the weakening and southward displacement of 65 westerlies to mid-latitudes. Winter moisture variation in south- 66 western France is, as in Iberia, negatively correlated to the NAO (Trigo 67 et al., 2002). While a NAO-like pattern has been proposed to explain 68 fuel availability and therefore fire regime during GS and GI in 69 southwestern Iberia, we still do not know whether this atmospheric 70 mechanism was at hand in regions located further north.

This work has two main objectives: a) to document for the first 72 time the fire regime of western France during the LGP, and b) to 73 
examine whether the fuel amount is, as in southwestern Iberia, the main factor controlling the millennial-scale fire regime variability in this region. For this, we analysed microcharcoal particles preserved in deep-sea core MD04-2845 in the Bay of Biscay at the latitude of Bordeaux. Complementary analysis of organic carbon on this core has been carried out in order to understand better the microcharcoal signal. Preliminary $\delta^{8} \mathrm{O}$ isotopic measurements and previous studies of this core (carbonates, ice rafted debris, planktonic foraminifera, pollen) have shown that it covers Marine Isotope Stage (MIS) 7 to 1 and revealed the impact of D-O climatic variability and Heinrich events in the ocean and on land (Sánchez Goñi et al., 2008). The direct correlation between past fire regime and these climatic proxies, in particular vegetation shifts, allows the discussion of the complex relationships between fire and climate.

\section{Environmental setting}

Present-day vegetation, fire and climate

Western France extends from $42^{\circ} \mathrm{N}$ to $48^{\circ} \mathrm{N}$ (Fig. 1) and comprises essentially the Loire-Britany and the Adour-Garonne river basins. This region is characterised by a temperate and oceanic climate. Winter precipitation in its southern part is particularly influenced by the NAO (Trigo et al., 2002; Dupuis et al., 2006). Annual precipitation of the Loire-Britany basin is $500-700 \mathrm{~mm}$ and $600-1000 \mathrm{~mm}$ for the AdourGaronne basin. The specific region covered by mountains (the Massif Central and the Pyrenean) receive more than $1500 \mathrm{~mm}$. The mean temperatures in winter vary from 0 to more than $8^{\circ} \mathrm{C}$ on the Atlantic coast, and from 15 to more than $22^{\circ} \mathrm{C}$ in summer (Serryn, 1994). The region is colonised today by Atlantic vegetation (Fig. 1) characterised by deciduous forests (mainly oaks, ash, beech, birch) and coniferous 101 trees restricted to montane and some southern maritime areas, and by 102 semi-natural grasslands (Polunin and Walters, 1985).

Compared to Spain, Portugal, Italy and Greece, France does not experience a high fire activity. The average of 30,738 ha of burnt 105 wooded area and 5218 forest fires for the period AD 1980-2000 106 represent only $4 \%$ and $10 \%$, respectively, of that of the other countries 107 (European Commission, 2001). Fire activity in France is mainly 108 concentrated in its Mediterranean part, during summer months 109 (July and August). The western part of France is, on the whole, not 110 affected by large fires, but local fires caused by lightning do occur 111 (http://www.feudeforet.org/). However, as the present-day incidence 112 and spatial distribution of fires resulting from lighting strikes is 113 restricted by human activities, this type of ignition may have been 114 more important in the past.

\section{Oceanic surface circulation and wind patterns}

The current circulation pattern in the Bay of Biscay (Fig. 2) is 117 characterised by a mean southward surface circulation during 118 summer, the formation of eddies near the shelf break and a weak 119 flow of the slope current. During winter, the mean surface circulation 120 is dominated by a strong poleward intrusion of the slope current along 121 the Iberian Peninsula and the Armorican and Celtic slopes, with a 122 branch of westward orientation inside the Bay of Biscay, generating a 123 particular cyclonic cell circulation centred at $46^{\circ} \mathrm{N}, 6.5^{\circ} \mathrm{W}$ (Durrieu de 124 Madron et al., 1999; Colas, 2003). This poleward slope current (the 125 Navidad current) in the winter season brings warm surface water into 126 the Bay of Biscay and may affect biological productivity (Garcia-Soto et 127 al., 2002). Its strength depends on the wind pattern over the Bay 128

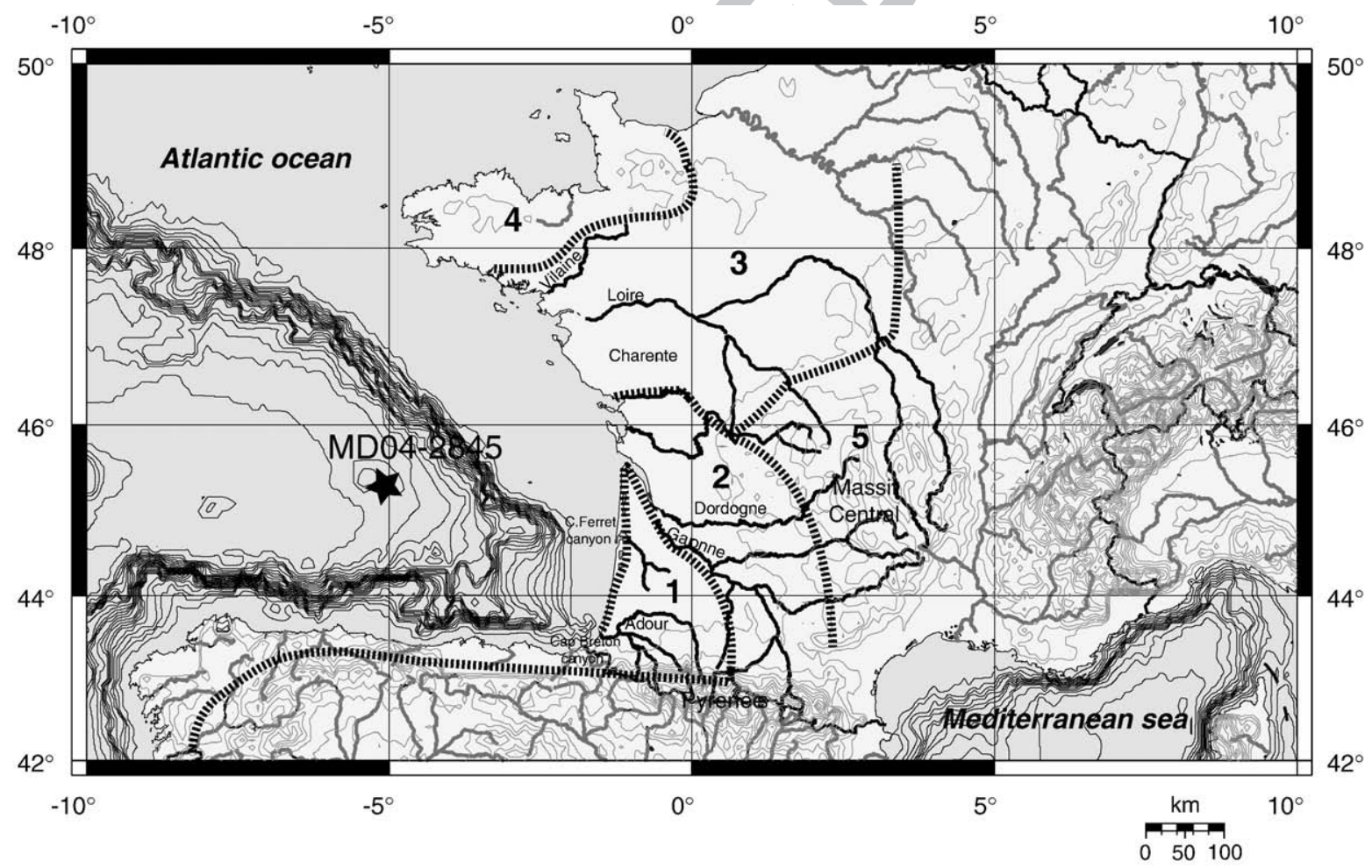



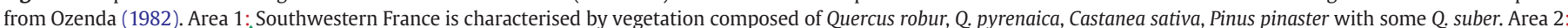

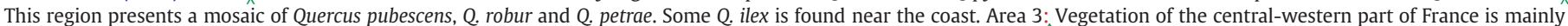

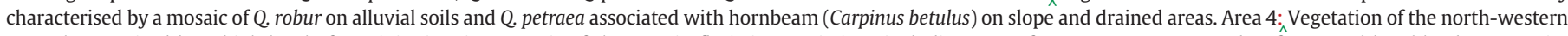



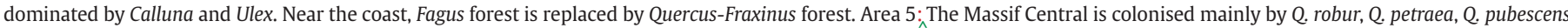

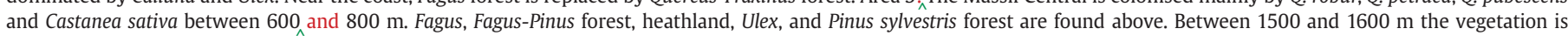
composed of heathland of Calluna and Juniperus sibirica. 


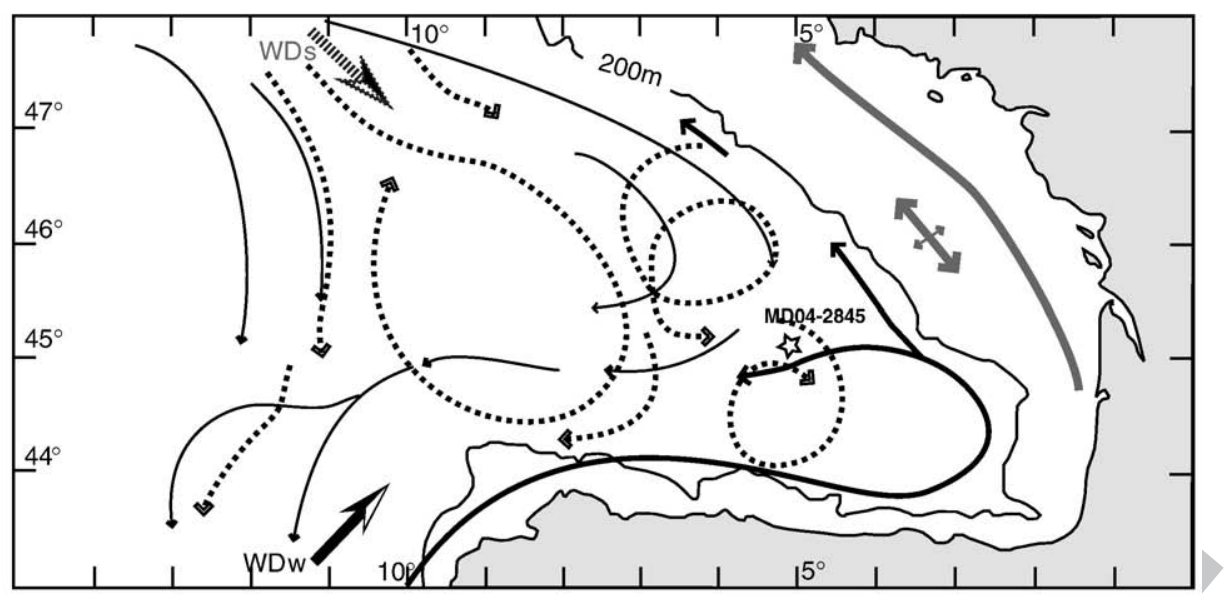

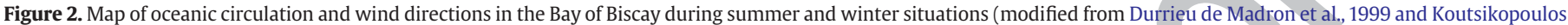

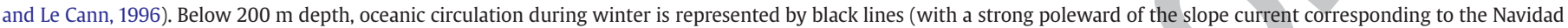

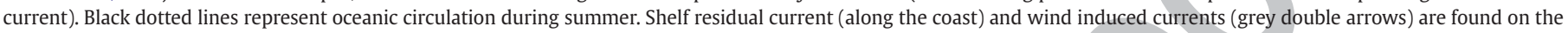
shelf. Arrows represent dominant wind directions. WD w (black arrow): wind direction in winter. WD s (grey dotted arrow): wind direction in summer.

related to the NAO, with a low NAO index leading to an intensified Navidad current (Garcia-Soto et al., 2002).

The mean wind direction over the Bay (Fig. 1) is from northwest in summer and from southwest in the winter season. However, a southward direction towards northern Iberia prevailed inside the bay for both situations (Colas, 2003). Upwellings appear during spring and summer period along the shelf area in relation to wind blowing to the coast (Heaps, 1980). Northwesterly to northerly wind events create coastal upwellings off southern Brittany, Vendée and Landes. Westerly winds generate upwelling to the north of the Loire (Froidefond et al., 1996; Lazure and Jégou, 1998; Puillat et al., 2004). Core MD04-2845 is outside of these upwelling areas.

\section{Morphology and recent sedimentation}

The Bay of Biscay is characterised by a continental shelf oriented NW-SE along the French coast and E-W along the Spanish coast, with a platform relatively flat. Its large width along the French coast prevents direct feeding on the shelf break by bottom nepheloid layers (Jouanneau et al., 1999) except for the region of the Cap-Ferret Canyon (Ruch et al., 1993). Two sedimentary systems characterise the continental shelf of this bay, an inner shelf $(<100-120 \mathrm{~m})$ and an outer shelf $(>120 \mathrm{~m})$ showing a general grain-size fining southward (Allen and Castaing, 1977). Pre- and early Holocene offshore mud and sands occupy the zone between 75 and $120 \mathrm{~m}$ depth, and coarse sands and gravels carried by rivers between $30-75 \mathrm{~m}$, probably related to the influence of the Gironde paleoriver detected $50 \mathrm{~km}$ seaward of the estuary mouth (Lericolais et al., 2001).

Rivers (Fig. 1) are the main sources of fine sediments (including microcharcoal and pollen) to the Bay of Biscay, taking into account that westerlies are the dominant winds in the Bay. The main rivers, the Garonne and the Dordogne feeding the Gironde estuary, the Loire, the Vilaine, the Charente and the Adour rivers, deliver about $2.5 \times 10^{6} \mathrm{t} \mathrm{yr}^{-1}$ of continental fine sediments, with the Gironde estuary accounting for $60 \%$ of this amount (Jouanneau et al., 1999). The continental suspended matter which spreads out from the Gironde estuary on the shelf is transported to the north along the coast by a surface turbid plume (Castaing, 1981) and may be carried to the Cap-Ferret Canyon in a bottom nepheloid layer (Ruch et al.,


reach the slope and eventually the open ocean (Jouanneau et al., 1999).

Experimental studies on the present-day pollen-vegetation relationship confirms that marine pollen assemblages from the south- western French margin represent an integrated image of the regional 171 vegetation, including coastal, low and high altitude areas (Turon, 172 1984). Pollen assemblages preserved in core MD04-2845 therefore 173 reflect the vegetation colonising both hydrographic basins with 174 headwaters located in the Massif Central and the Pyrenees, 175 respectively.

Materials and methods

Core location, sampling and chronostratigraphy

178

Deep-sea core MD04-2845 $\left(45^{\circ} 21^{\prime} \mathrm{N}, 5^{\circ} 13^{\prime} \mathrm{W} ; 4175 \mathrm{~m}\right.$ water 179 depth) (Fig. 1) was collected during the Alienor cruise in 2004 in 180 the Bay of Biscay using the CALYPSO Kullenberg corer aboard the 181 Marion Dufresne vessel. The site is located $350 \mathrm{~km}$ from the 182 nearest coastline on the Gascogne Seamount, without influence of 183 turbidite currents. The sediments are mainly composed of clayey 184 mud with sparse silty laminations, with 10-65\% carbonate. 185 Observations of X-ray analysis using SCOPIX image-processing 186 have shown a well preserved sedimentary sequence not perturbed 187 by turbidites in the analysed part of core MD04-2845 between 760188 and $2245 \mathrm{~cm}$ depth. A sedimentary hiatus appears between 1714189 and $1740 \mathrm{~cm}$ depths.

Carbonate content measurements and onboard sediment 191 reflectivity curve along with IRD counting, polar foraminifer 192 Neogloboquadrina pachyderma (s) percentages and foraminifer 193 assemblage-derived sea surface temperatures (SST) of core 194 MD04-2845 define the last interglacial, D-O events and Heinrich 195 events. To compare fire regime of western France with that 196 recorded in southwestern Iberia (Daniau et al., 2007), the age 197 model of the marine core MD04-2845 is based on that of the 198 southern Iberian margin core MD95-2042 (37 $\left.14^{\prime} \mathrm{N}, 10^{\circ} 11^{\prime} \mathrm{W}\right), 199$ which is AMS ${ }^{14} \mathrm{C}$ dated and calibrated to GISP2 and GRIPSS09sea 200 chronologies, assuming that changes in the polar front position 201 were synchronous in the North Atlantic region (Shackleton et al., 202 2000, 2004; Bard et al., 2004). Control points used for the glacial 203 interval of core MD04-2845 are derived from the correlation of 204 the onset of GI and boundaries of HE detected in this core with 205 those identified in core MD95-2042 (see synthetised table in 206 Sánchez Goñi et al., 2008).

For the interval $680-892 \mathrm{~cm}$ (Table 1 ), we add 4 control points 208 derived from the age model of the Iberian core used in Daniau et al. 209 (2007). Ages of these control points are in good agreement with linear 210 age model obtained from 10 AMS ${ }^{14} \mathrm{C}$ ages obtained for core MD04- 211 
t1.1 Table 1

Chronostratigraphic model for core MD04-2845

\begin{tabular}{|c|c|c|c|c|c|c|c|c|}
\hline Lab code/event & Core depth (m) & Material & $\begin{array}{l}\text { Conv. AMS }{ }^{14} \mathrm{C} \text { age } \\
\mathrm{kyr}(-400 \mathrm{yr})\end{array}$ & Error yr \pm & $\begin{array}{l}95.4 \%(2 \sigma) \mathrm{Cal} \\
\text { BP age ranges }\end{array}$ & $\begin{array}{l}{ }^{(1)} \text { Cal BP age (ka) } \\
\text { median probability }\end{array}$ & $\begin{array}{l}{ }^{(2)} \text { Bard et al. (2004) } \\
\text { age (ka) }\end{array}$ & $\begin{array}{l}\text { (3) Control points (ka) based } \\
\text { on MD95-2042 chronology }\end{array}$ \\
\hline SacA-002960 & 5.2 & G. bulloides & 16.890 & 150 & $19.782: 20.365$ & 20.03 & & \\
\hline HE2/GIS2 & 6.8 & & & & & & & 23.95 \\
\hline SacA-002961 & 6.9 & N. pachyderma (s) & 20.420 & 140 & $24.016: 24.890$ & 24.44 & & \\
\hline SacA-002962 & 7.1 & N. pachyderma (s) & 20.710 & 140 & $24.426: 25.405$ & 24.88 & & \\
\hline SacA-002963 & 7.7 & N. pachyderma (s) & 21.860 & 160 & & & 25.82 & \\
\hline SacA-002964 & 7.9 & N. pachyderma (s) & 22.150 & 170 & & & 26.14 & \\
\hline Base HE2 & 8.1 & & & & & & & 26.25 \\
\hline SacA-002965 & 8.5 & G. bulloides & 24.050 & 210 & & & 28.22 & \\
\hline Onset GIS3 & 8.5 & & & & & & & 27.84 \\
\hline SacA-002966 & $8.6^{\mathrm{a}}$ & N. pachyderma (s) & $24.680^{\mathrm{a}}$ & 230 & & & $28.89^{a}$ & \\
\hline SacA-002967 & $8.7^{\mathrm{a}}$ & N. pachyderma (s) & $24.630^{\mathrm{a}}$ & 230 & & & $28.84^{\mathrm{a}}$ & \\
\hline SacA-002968 & $8.9^{\mathrm{a}}$ & G. bulloides & $25.230^{\mathrm{a}}$ & 240 & & & $29.48^{\mathrm{a}}$ & \\
\hline HE3/GIS4 & 8.92 & & & & & & & 29.00 \\
\hline SacA-002969 & $9.0^{\mathrm{a}}$ & N. pachyderma (s) & $24.870^{\mathrm{a}}$ & 240 & & & $29.10^{\mathrm{a}}$ & \\
\hline
\end{tabular}

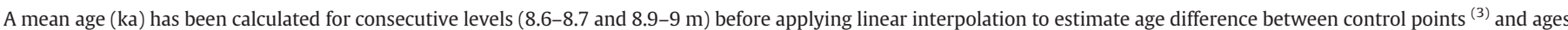
A mean age $(\mathrm{ka})$ has been calculated
based on calibrated $\mathrm{AMS}^{14} \mathrm{C}^{(1,2)}$.

${ }^{a}$ Levels presenting small $\mathrm{AMS}^{14} \mathrm{C}$ inversions.

2845 in the interval HE3/GI4 to HE2/GI2 (mean age difference $<400 \mathrm{yr}$ ). The samples presenting conventional AMS ${ }^{14} \mathrm{C}$ younger than $21,786{ }^{14} \mathrm{C}$ yr BP were calibrated by using CALIB Rev 5.0 program and "global" marine calibration data set (marine 04.14c) (Stuiver and Reimer, 1993; Hughen et al., 2004; Stuiver et al., 2005). ${ }^{14} \mathrm{C}$ radiometric ages older than $21,786{ }^{14} \mathrm{C}$ yr BP were calibrated by matching the obtained conventional AMS ${ }^{14} \mathrm{C}$ with the calendar ages estimated for MD95-2042 deep-sea core by Bard et al. (2004).

The core was sampled every $5 \mathrm{~cm}$ between $2245 \mathrm{~cm}$ and $760 \mathrm{~cm}$ for microcharcoal and organic carbon content analyses; this interval encompasses the end of MIS 6 to MIS 2.

\section{Image analysis for microcharcoal counting}

A total of 294 samples were analysed for microcharcoal using automated image analysis in transmitted light. Microcharcoal preparation technique followed the work of Daniau et al. (2007). Chemical treatment was performed over $24 \mathrm{~h}$ on $0.2 \mathrm{~g}$ of dried sediment and involved the addition of $5 \mathrm{~mL}$ of $37 \% \mathrm{HCl} ; 5 \mathrm{~mL}$ of $68 \%$ $\mathrm{HNO}_{3} ; 10 \mathrm{~mL}$ of $33 \% \mathrm{H}_{2} \mathrm{O}_{2}$. This chemical treatment is used to remove pyrites, humic material, labil or less refractory organic matter (OM) and to bleach non-oxidised OM. Dilution of 0.1 was then applied to this residue and this suspension was filtered onto a cellulose acetate membrane containing nitrocellulose of $0.45 \mu \mathrm{m}$ porosity and $47 \mathrm{~mm}$ in diameter. A portion of the membrane was dissolved onto a plexiglass slide with $\overline{\bar{\equiv}}$ l acetate before gentle polishing with alumin powder of 200 . The use of polish slide (used classically in petrographic analysis) for image analysis is better than the previously assembling technique consisting of mounting the portion of the membrane onto a slide with Canadian balsam (Daniau et al., 2007) as the focus on the edge of microcharcoal is improved. The slides were scanned with an automated Leica DM6000M microscope at $\times 500$ magnification. In order to have a good statistical representation of each sample, 200 view-fields (200 images) of $0.0614 \mathrm{~mm}^{2}$ were "grabbed" in color with a $1044 \times 772$ pixels digitising camera ( 1 pixel $=0.276 \mu \mathrm{m}$ ). The surface scanned by the microscope represents a surface area of $12.279 \mathrm{~mm}^{2}$.

Microcharcoal recognition was performed by using a program of image analysis developed in this study with LeicaQwin software. The subroutine written for microcharcoal identification during image analysis procedure was established by a simultaneous visual identification of microcharcoal in transmitted light following criteria from Boulter (1994), namely black debris, opaque, with sharp edges (see also Enache and Cumming, 2006) and petrographic criteria in reflected light, that is with visible plant structures characterised by thin cell walls and empty cellular cavities, or particles without plant structure but of similar 256 reflectance than that of previous ones (Noël, 2001). In a controlled 257 light adjustment, a threshold value in red, green, blue (RGB) color 258 was defined to identify microcharcoal based on several observa- 259 tions of particle on different slides.

From measured variables of microcharcoal (surface area, length, 261 width, elongation, number) we calculated for each sample:

a) the concentration of microcharcoal (CCnb): number of micro- 263 charcoal per gram $\left(\mathrm{nb} \mathrm{g}_{\wedge}^{-1}\right)$

264

b) the concentration of microcharcoal surface (CCsurf), which is the sum 265 of all surfaces of microcharcoal in one sample per gram $\left(\mu \mathrm{m}^{2} \mathrm{~g}_{\wedge}^{-1}\right) \cdot 266$ This is to avoid the overrepresentation of microcharcoal concentra- 267 tion as the result of potential fragmentation during production 268 (Théry-Parisot, 1998) or transport.

The three-point running mean "MCCnb" and "MCCsurf" was also 270 calculated for CCnb and CCsurf respectively to be able to compare fire 271 regime with vegetation history of the same core (resolution of $10 \mathrm{~cm}$ ). 272 The term MCC will be used as global mean average microcharcoal 273 concentration representing microcharcoal concentration variation of 274 number or surface of microcharcoal (as the two microcharcoal 275 concentrations covary, see below).

Replicate analysis was done on 10 samples randomly selected of 277 core MD04-2845, analysed ten times each. Experimental standard 278 deviations were calculated with the equation below. The con- 279 fidence interval at 95\% (see curve in Fig. 3) is derived from the 280 Student's $t$-distribution for $n-1$ degrees of freedom $\left(x_{i} \pm t^{*} s\right.$ with 281 $t=2.262$ ).

$s=\sqrt{\frac{1}{n-1} \sum_{i=1}^{n}\left(x_{i}-\bar{x}\right)^{2}}$

The minimum of variation of MCC discussed below is higher than the 283 widen confidence interval so that variations observed in MCC curve 285 are not related to an artefact of sampling bias.

Particulate ${ }_{\wedge}$ organic carbon (POC) analysis

The organic carbon (OC) content was determined directly on dry 288 weight material sediment by combustion in an LECO CS 200 analyzer 289 (Etcheber et al., 1999) on the same sample depth as that used for 290 microcharcoal analysis. Around $50 \mathrm{mg}$ of powdered and homo- 291 genized samples were acidified in crucibles with $2 \mathrm{~N} \mathrm{HCl}$ to destroy 292 carbonates and then dried at $60^{\circ} \mathrm{C}$ to remove inorganic carbon and 293 most of the remaining acid and water. The OC analysis was 294 performed by direct combustion in an induction furnace, and the 295 


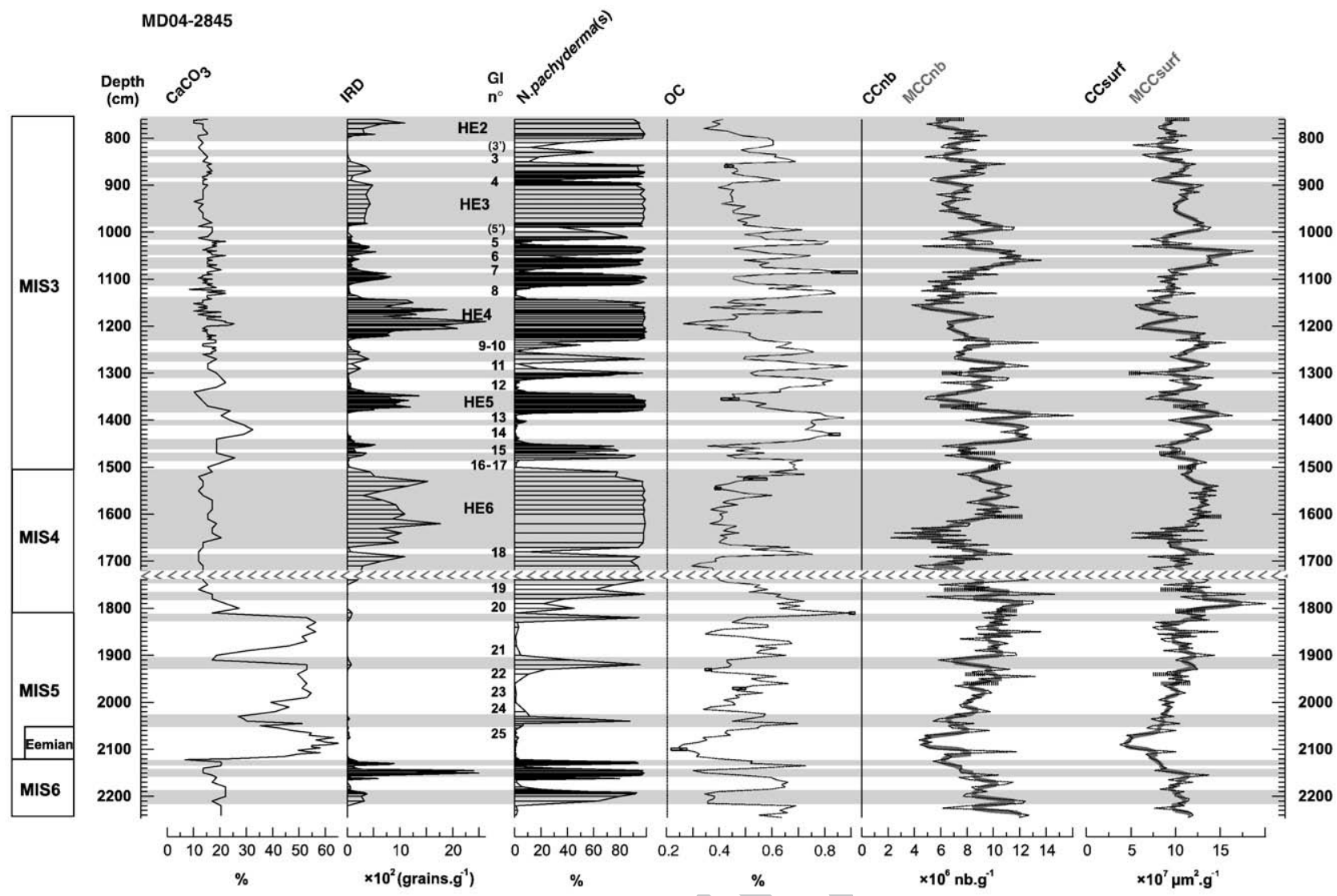

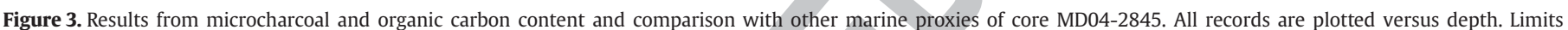

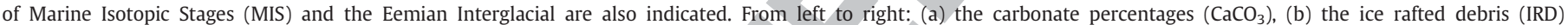

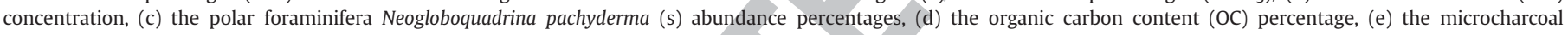

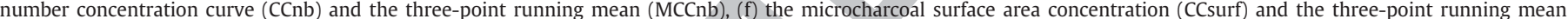

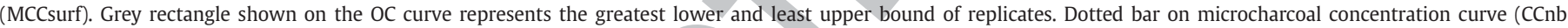

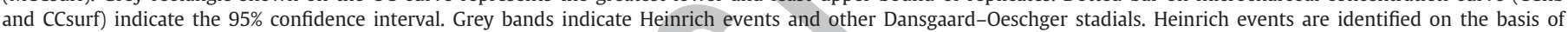


sedimentary hiatus.

$\mathrm{CO}_{2}$ formed was determined quantitatively by infrared absorption. Replicate analyses were performed on 10 selected samples reanalysed 6 times each (greatest lower and least upper bound are indicated in Fig. 3).

\section{Results}

\section{Microcharcoal analysis}

Concentration of CCnb varies between $218.4 \times 10^{4}$ and $1607 \times 10^{4}$ $\mathrm{nb} \mathrm{g}^{-1}$ (Fig. 3). Concentration of CCsurf varies between $3731 \times 10^{4}$ and $20,137 \times 10^{4} \mu \mathrm{m}^{2} \mathrm{~g}_{\wedge}^{-1}$. CCnb and CCsurf are positively correlated $\left(r=0.75 ; R^{2}=0.56\right)$. Visual inspection of MCCnb and MCCsurf reveals high variability superimposed to a long-term trend. A long-term decreasing trend characterises the end of MIS 6 until the middle part of the Eemian, the MIS 4 until the beginning of HE6, and the intervals between GI14-HE4 and GI6-HE2. A long-term trend of increasing values of MCC occurs from the end of the Eemian to the onset of MIS 4.

The high variability of MCCnb and MCCsurf superimposed to the long-term trend shows low values or decreasing values during stadials of MIS 5 and 6 (except GS20), and during GS and HE except for the middle part of HE6 and 4, GS8, GS7, GS4 and GS3. Each of HE are characterised by three phases: a phase of relatively high MCC bracketed by two phases of low MCC. A pronounced decrease of MCC occurs at the end of HE4 and HE3, while HE6 presents a rather different pattern with a strong decrease of MCC at the beginning of 319 the event.

Organic carbon (OC)

The OC of core MD04-2845 (Fig. 3) varies between 0.248 and 322 $0.903 \%$ (average value of $0.53 \%$ ) which is comparable to the OC 323 reported in the Bay of Biscay for sediments from the shelf $(<0.5 \%)$ or 324 deep ocean (average value: 0.5-1\%) (Etcheber et al., 1999). The OC 325 values are comparable between the last interglacial (average value of 326 $0.49 \%$ ) and the LGP (average value of $0.55 \%$ ). The OC is highly variable 327 for the LGP and parallels the D-O climatic variability with high values 328 during GI and low values during GS and HE. During the last interglacial 329 period, three gradual increases of OC occurred during the Eemian- 330 GS25, GI23-22, GI21 and GI20. The end of MIS 6 presents the same 331 pattern than the LGP with peaks of OC corresponding to interstadials 332 and low values of OC during stadials.

333

Time-series analysis

To extract the significant periodicities of our proxies, spectral 335 analysis was applied on linear detrended OC content and micro- 336 charcoal concentration (CCsurf and CCnb) before applying the Lomb 337 periodogram algorithm (Past software). Periodicities have been 338 selected for a 0.01 (99\%) significance level. Several millenial 339 periodicities are detected in the proxies (see Fig. 4). Most notably, 340 


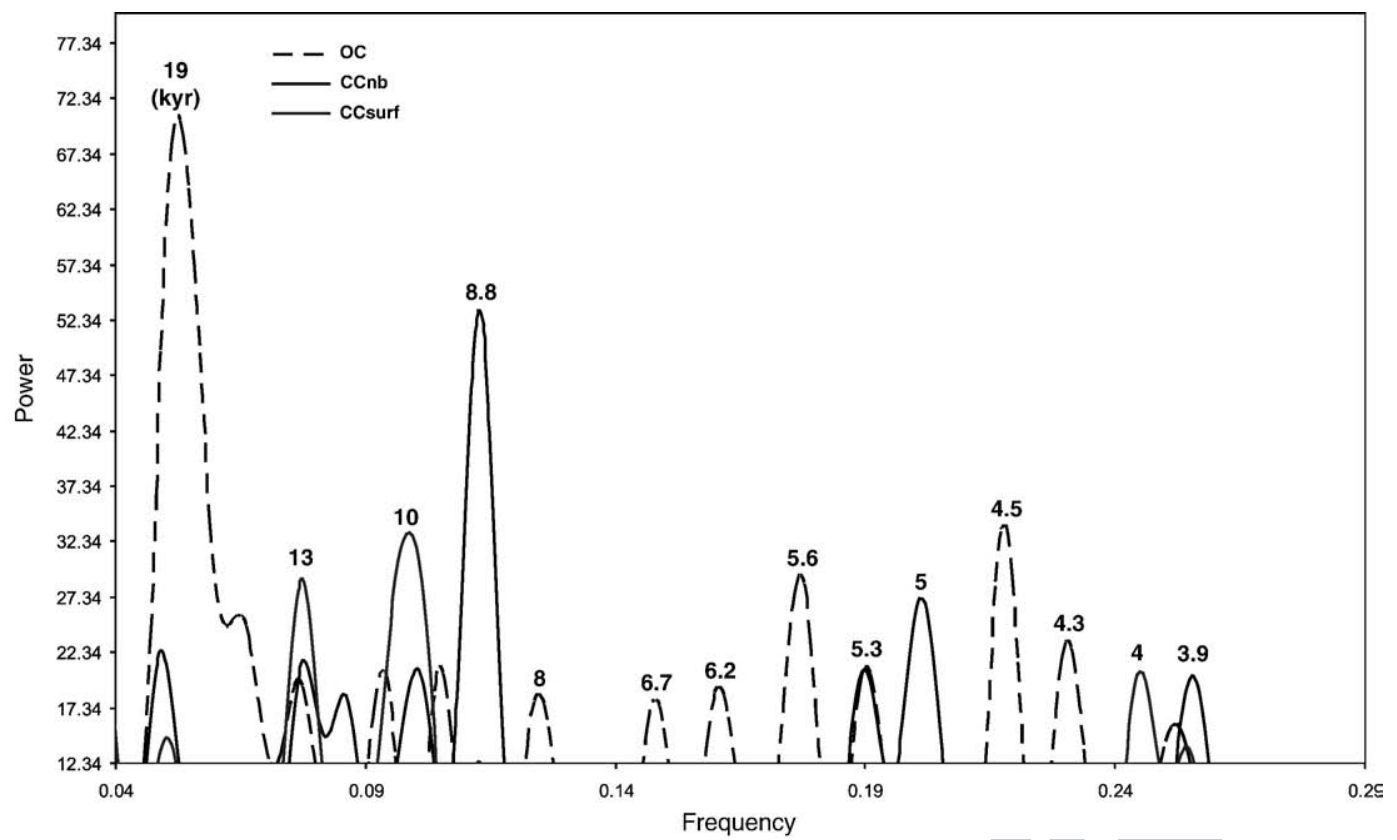

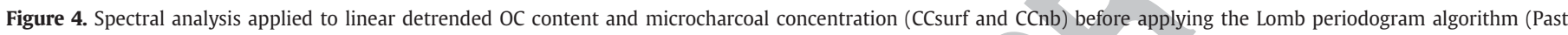

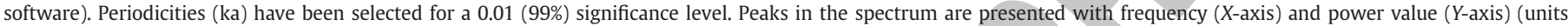
proportional to the square of the amplitudes of the sinusoids present in the data).

periods close to the precession (19-20 ka) are detected for OC and microcharcoal concentration. CC presents well marked periods of 13 , 10 and $8.8 \mathrm{ka}$.

\section{Discussion}

Last glacial oceanic circulation and wind direction changes: implications for microcharcoal signal interpretation

In order to test whether millenial-scale MCC variation is related to actual changes in fire regime and to verify that MCC variation is independent of changes in aeolian or fluvial sedimentary input, we have used other climatic proxies (pollen, foraminifera derived-SST, $\mathrm{OC}$ and $\mathrm{CaCO}_{3}$ ). OC content parallels the $\mathrm{D}-\mathrm{O}$ climatic variability with an alternation of high and low OC values during GI and GS, respectively (Fig. 3). OC content in marine cores is derived from marine productivity although a fraction of continental material may affect it (Pailler and Bard, 2002). The absence of correlation over the record of core MD04-2845 between OC and terrestrial material such as microcharcoal and pollen $(r=0.34, p<0.01$ for OC content and microcharcoal concentration, $r=0.16, p<0.1$ for $O C$ and pollen concentration) implies that such $\mathrm{OC}$ variations cannot be explained only by changes of continental organic matter supply via wind or rivers. Additionally, $\mathrm{CaCO}_{3}$ being free of dissolution because of the core location above the carbonate compensation depth (Kennett, 1982), no significant correlation between $\mathrm{OC}$ and $\mathrm{CaCO}_{3}$ contents $(r=$ $-0.13, p<0.02$ ) indicates that the OC might derive from noncalcifying species such as diatoms or silicoflagellates. Coccoliths such as Emiliana huxelyi, Gephyrocapsa and Coccolithus pelagicus, which are currently associated with an increase of diatoms and silicoflagellates in this region (Beaufort and Heussner, 1999), were indeed observed during interstadials in our core (e.g., GI 17-16, J. Giraudeau, pers. comm.). This suggests that an increase of OC during GI reflects an increase of marine productivity. The OC pattern in core MD04-2845 is similar to the pattern of dinoflagellates productivity in the marine core MD03-2692 located on the Celtic margin during MIS 6 , where higher concentrations during interstadials and lower ones during stadials are observed (Penaud, unpublished data). We there- fore consider $\mathrm{OC}$ to be essentially a proxy of marine productivity in 376 core MD04-2845.

Last glacial productivity changes revealed by a core located off 378 Lisboa were related to variations in Portugal's upwelling system 379 (Pailler and Bard, 2002). However, the Gascogne seamount is far from 380 regions affected today by upwellings in the Bay of Biscay, namely the 381 shelf break or river plumes. This site was also outside the direct 382 influence of upwelling during the LGP because the shelf break was still 383 drowned at the maximum lowstand sea level (maximum of $-120 \mathrm{~m} 384$ depth for the last glacial maximum). Therefore, a different mechanism 385 to that explaining the OC content variation in the Iberian margin must 386 be responsible for the observed shifts in OC between GS and GI in our 387 core.

Forest development detected in core MD04-2845 during GI (Fig. 5) 389 suggests an increase of temperatures and precipitation. At present, the 390 increase of humidity as well as river run-off in southwestern France is 391 related with the negative mode of the NAO (Trigo et al., 2002; Dupuis et 392 al., 2006). Climatic conditions in this region during GI might be related, 393 as suggested for southern Iberia (Combourieu Nebout et al., 2002; 394 Moreno et al., 2002; Sánchez Goñi et al., 2002), to a prevailing negative 395 NAO-like situation. Under this climatic regime, SST warming might 396 also be linked to enhanced influence of a warm paleo Navidad current, 397 as occurs today during negative NAO index (Garcia-Soto et al., 2002), 398 favouring productivity blooms and OC increase during the GI. More- 399 over, our hypothesis of the paleo-Navidad current strengthening under 400 a negative NAO-like mode during GI is consistent with the observed 401 weakening of Mediterranean Outflow Water (MOW) at that time 402 (Voelker et al., 2006; Toucanne et al., 2007). The formation of western 403 Mediterranean Deep Water, which likely was a major source of the 404 MOW during the last glacial (Myers et al., 1998; Voelker et al., 2006), is 405 at present positively correlated to the NAO (Rixen et al., 2005). 406

The comparison between this past oceanic scenario pattern with 407 the modern oceanic and atmospheric circulations (Fig. 2) suggests that 408 GI would be, as in the modern situation, more influenced by 409 southwesterly winds (winter situation) than GS periods that were 410 characterised by prevailing northwesterlies (summer situation). As 411 both wind systems come from the ocean, we do not expect therefore a 412 substantial aeolian contribution of microcharcoal to the Gascogne 413 
Age


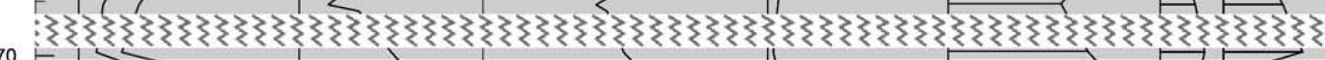

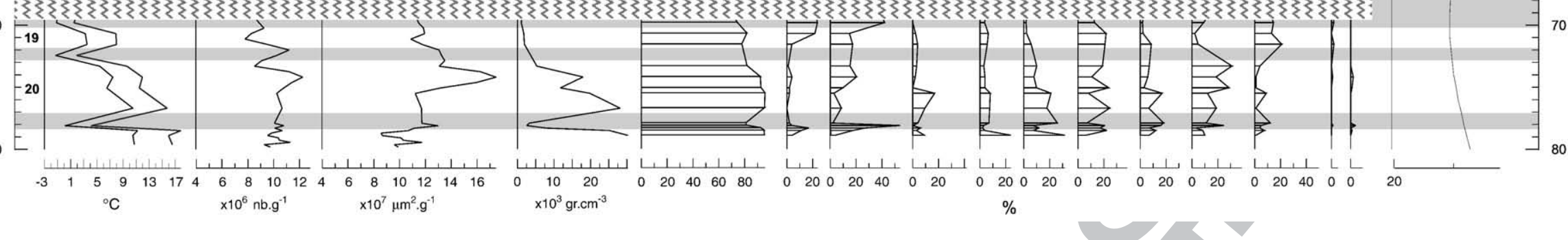

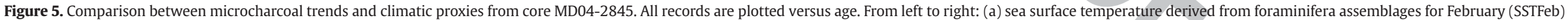

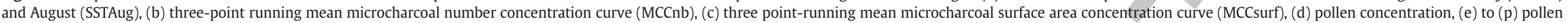




Atlantic forest. 68-70 ka: sedimentary hiatus. 
seamount during the different phases of the LGP. This is also supported by the sporadic presence of the North African windpollinated Cedrus tree pollen in the record (Fig. 5), which suggests negligible input of charcoal coming from the South. As with other regions in western Europe (Van Huissteden et al., 2001), the Bay of Biscay was likely characterised by prevailing westerlies during the LGP, suggesting that MCC variability is not controlled by changes in wind directions.

MCC variation in core MD04-2845, retrieved at $350 \mathrm{~km}$ from the coast and on a seamount, would be only affected by dilution related to the biogenic or terrigenous hemipelagic input or changes in fluvial sedimentary transfer. The lack of correlation between non-carbonate sedimentary fraction $\left(1-\mathrm{CaCO}_{3}\right)$ or carbonates and microcharcoal concentration ( $r= \pm 0.408$ with CCnb, or $r= \pm 0.21$ with $\operatorname{CCsurf}\left(p_{\wedge}<0.01\right)$ ) for the LGP suggests that neither biogenic nor terrigenous material dilute microcharcoal concentration and that MCC variation is not related to changes in fluvial discharges.

MCC variation is therefore not related to changes in aeolian or fluvial sedimentary input, implying that changes in MCC represent variation in regional microcharcoal production and, therefore, in fire regime of western France. Intervals of high MCC values identify periods of strong fire regime, while those marked by low values reveal weak fire regime phases.

\section{Fire regime, vegetation composition and climate in western France} during the last glacial period

Fire regime is highly variable all along the record, especially during the LGP (Fig. 5): low fire regimes are detected during GS and HE and high fire regimes during GI. This strong fire regime variability may reflect climatic changes, namely succession of dry and humid periods, involving shifts in lightning storm position, changes in fire-sensitive species or variations in fuel availability. In addition, variations of fire regime have likely an impact on vegetation succession. In order to discuss short and long-term fire-climate-vegetation relationship we have compared fire regime changes and fluctuations in vegetation cover and composition (Fig. 5). The vegetation of core MD04-2845 shows that Betula-Pinus-deciduous Quercus forest expanded during GI and steppic plants (Artemisia, Poaceae, heaths and sedges) dominated during the cold and dry GS (Sánchez Goñi et al., 2008).

No continuous and well dated pollen terrestrial records identifying the millennial-scale variability are available in western France. Only the multiproxy study of the Cestas soil, located in southwestern France and reliably related with HE2 (Bertran et al., 2008), sheds light on local vegetation environments at low altitudes. These environments are similar to those described from marine pollen record MD04-2845 and mainly composed by steppic plants such as Poaceae, Helianthemum and Artemisia, sedges associated with local shrub dominated by Myrica and Ericaceae.

\section{Dansgaard-Oeschger interstadials and stadials}

Major differences in fire regime in western France between GS (low fire regime) and GI (high fire regime) are not associated with a particular taxon. Increase in fire regime is associated with periods of afforestation corresponding to the establishment of Betula-Pinusdeciduous Quercus open forest during GI, and low fire regime with steppic plants during GS. Some increase of fire regime are also associated to certain peaks of Ericaceae and Calluna on which repeated fires encourage their regeneration (Bradshaw et al., 1997; Mouillot et al., 2002; Calvo et al., 2002). Beyond the influence of the type and density of the vegetation on the fire regime through changes in fire frequency or severity, increase of microcharcoal concentration during periods of afforestation suggests the increase of microcharcoal production related to increase of woody fuel and biomass accumulation during GI as total plant biomass in forested areas is generally higher than open ground formations (Magri, 1994). This increase of woody fuel during GI indicates an increase of humidity and associated 477 sea and air surface temperature warming as likely the result of a 478 prevailing negative NAO-like index.

Increase of fire regime related to woody fuel availability for the LGP 480 has been already suggested by Daniau et al. (2007) for southwestern 481 Iberia and inferred from the strong correlation between MCC and 482 forest percentage curves. This hypothesis is supported by the 483 simulation of $\mathrm{Ni}$ et al. (2006) for semi-arid regions where lack of 484 fuel, related to drought, often limits the incidence of fire. Although the 485 relationship between fire regime and fuel changes occurs also in 486 western France during the LGP, the tight correlation found in Iberia is 487 less evident in western France. This suggests that in addition to fuel, a 488 direct climatic control may have operated on the fire regime 489 variability of the latter region during the LGP. The reason may be 490 that D-O climatic variability has a lesser impact on vegetation shift 491 between GS and GI which allows the development of a mosaic of 492 vegetation with a dominance of grasses through both GS and GI. At 493 present, a sharp contrast of precipitable water exists in Iberia between 494 negative NAO (high precipitation) and positive NAO (marked drought) 495 situations. Although the same pattern occurs in southwestern France, 496 the contrast of precipitable water is less marked in this region (Trigo et 497 al., 2002). Sánchez Goñi et al. (2008) show that the boundary of the 498 Mediterranean region was similar to that of the present-day during GI. 499 This would imply that a similar gradient of precipitable water than 500 that observed at present-day between the two regions may occur 501 during GI and suggests that during GS (positive NAO-like situation), 502 moisture content in western France is sufficient to develop a 503 continuous vegetation cover, mainly grasses, while lack of winter 504 moisture in southwestern Iberia triggered the development of semi- 505 desert vegetation.

Zooming in on Heinrich events 6, 5 and 4

The vegetation of HE 6, 5 and 4 (Fig. 6), mainly composed of Pinus 508 woodlands, some Picea (well developed during HE6), Sphagnum, Cal- 509 luna, and Cyperaceae species, is typical of present-day Boreal or 510 central European vegetation, characterised by evergreen coniferous 511 forest and mires which indicate high rainfall areas (Polunin and 512 Walters, 1985). The relative high percentages of Artemisia during HE 513 indicates this species occupies drier soils.

Heinrich event 4. Fire regime during HE4 presents a three-phase 515 structure (Fig. 6a). Decrease of fire regime at the beginning of HE4, 516 phase (a), is contemporaneous with a large reduction by 50\% of Pinus 517 percentages contemporaneous with the succession of Cyperaceae, 518 Sphagnum and Calluna progressively dominating the pollen assem- 519 blage. Succession of Cyperaceae and Sphagnum indicates progressive 520 colonisation of water-filled depressions by fens (minerotrophic peat- 521 land) then by bogs (ombrotrophic), which is the typical ecological 522 succession of peatland (mire) (McNamara et al., 1992). This plant 523 succession suggests also a vegetation of transitional mire which forms 524 a mosaic of bog and fen, or occurs where bog and fen succeed each 525 other (Polunin and Walters, 1985). Whereas the development of 526 Sphagnum indicates moist or waterlogged environments, this species 527 colonises the upper part of the water table (Rochefort et al., 2002). 528 Most Sphagnum species are absent or poorly represented in habitats 529 with an extremely fluctuating water table compared to Calluna 530 vulgaris which prefers considerable fluctuations (Laitinen et al., 2007). 531

The progressive dominance of Calluna at the end of this phase and 532 the disappearance of Sphagnum suggests an increase of the water 533 table and surface runoff produced by higher precipitation. Even if 534 summer convective rain would promote fire ignitions, relative strong 535 moist conditions would have slowed down fire propagation, leading 536 to the decrease of fire regime during the first phase of HE4, in 537 particular in a low fuel availability environment. Increase of fire 538 regime period, phase (b), starts with the beginning of Pinus forest 539 development associated with the decline of Calluna and the weak 540 


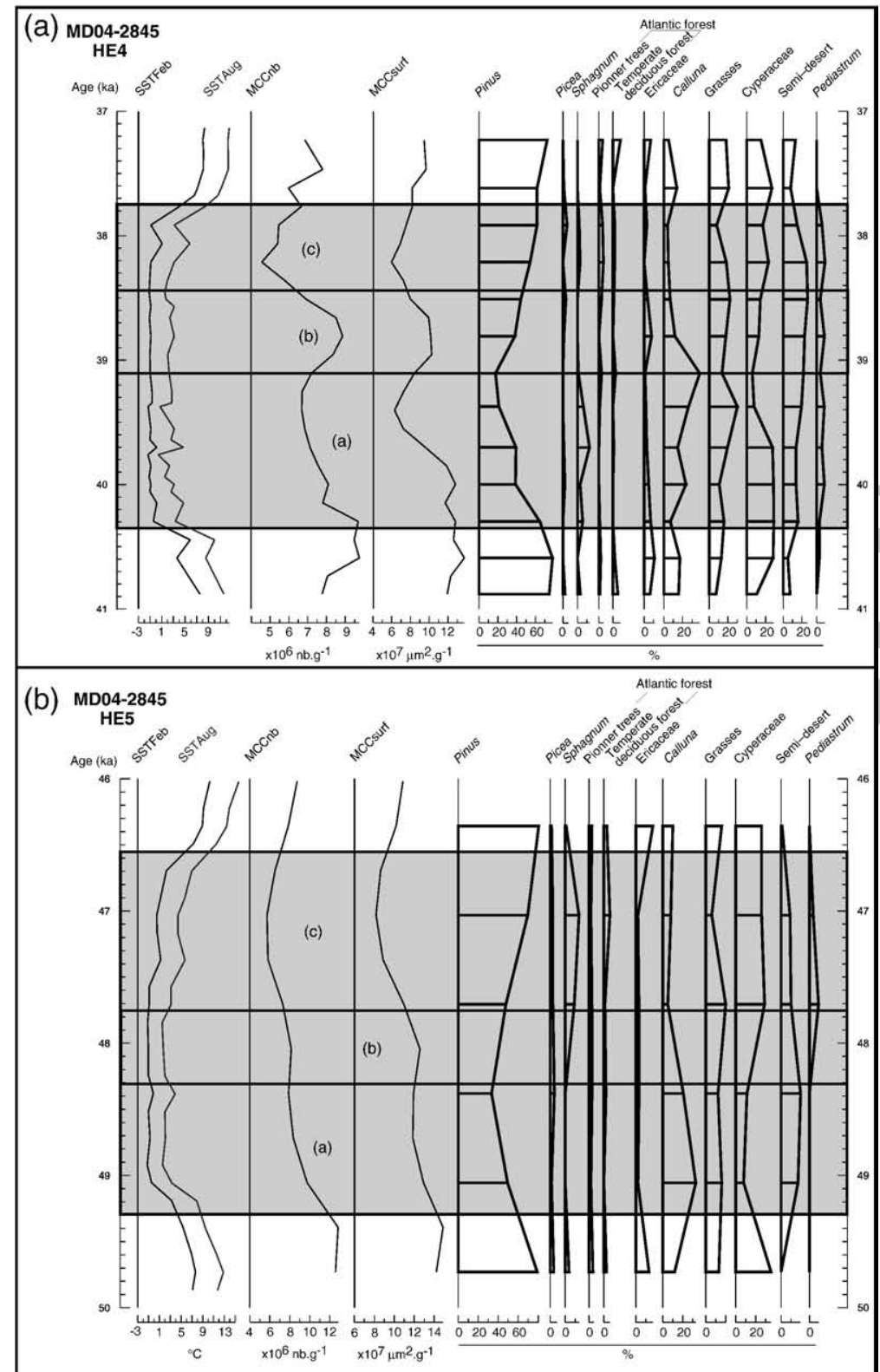

(c) MD04-2845

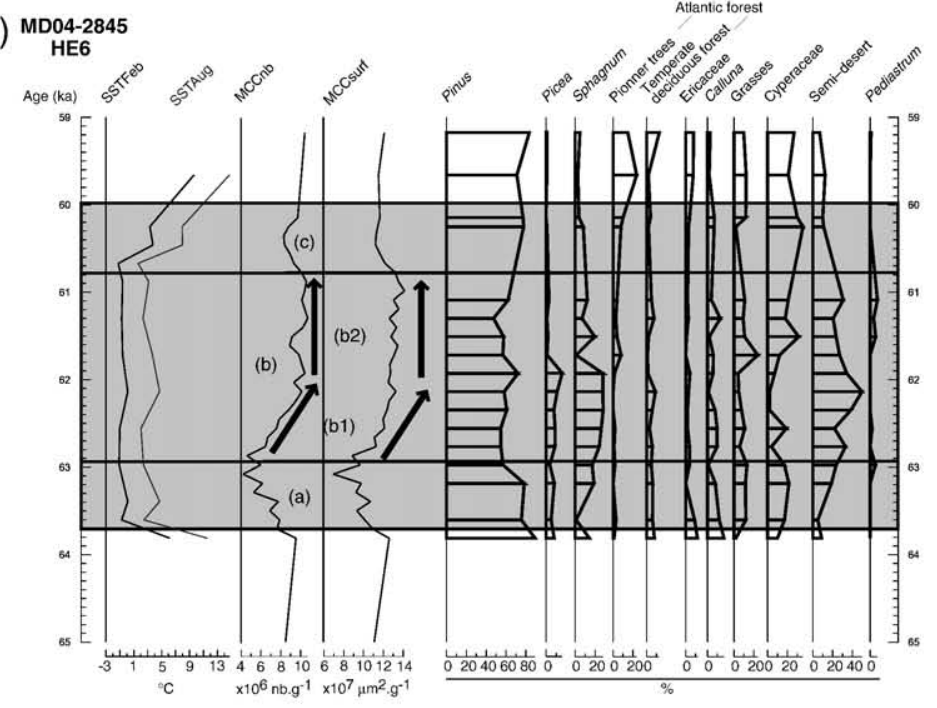

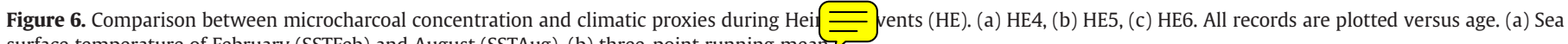
surface temperature of February (SSTFeb) and August (SSTAug), (b) three-point running mean 
development of other Ericaceae and semi-desert vegetation. This increase of fire regime contemporaneous with increasing fuel and a decrease of summer precipitation inferred from the decrease of Calluna would reflect environmental conditions favourable to fire propagation.

The decrease of fire regime in phase (c) at the end of HE4 is, at first sight, paradoxically associated with the development of mixed-wood forest (Pinus, Picea and Atlantic forests). The dominance of Cyperaceae and the new development of Sphagnum suggest again the development of mire. Although fire regime is expected to increase during this period as woody fuel is available, this wet environment might not promote fire spread, except at the very end of HE4 when Picea forest was more developed.

Heinrich event 5. As for HE4, three phases in the fire regime characterised HE5 (Fig. 6b). The decrease of fire regime in phase (a) occurs during a humid phase of low woody fuel (Pinus forest decline and Calluna-dominant vegetation). The relative low resolution of the pollen record during phase (b) precludes discussing the relationship between the increase of fire regime revealed by MCC and changes in forest cover and composition. The hypothesis of environmental conditions similar to HE4's phase (b) controlling this fire regime enhancement needs to be confirmed by higher resolution pollen analysis. The low fire regime in phase (c) is contemporaneous with Pinus forest and mire expansions. The record of Pediastrum at the very beginning of this phase suggests relative high amount of precipitation or strong snow melting favouring the development of water-filled depressions (lakes, ponds) or lowland rivers (Batten, 1996) during this time. The following succession of Cyperaceae and Sphagnum suggests the progressive colonisation of these water-filled depressions.

During HE4 and 5, the progressive increase of annual SST recorded in phase (c) contemporaneous with the development of Pinus forest suggests warmer conditions than that of previous phases. Further, Pinus forest development during the middle and the last phases of HE4 and 5 would be indicative of a transition from a wet and/or cold (phase (a)) to a dry and/or warm climate (phase (b-c)) inferred from the establishment of trees on peatlands (see a synthesis in Linderholm and Leine, 2004). This drying and warming trend, observed during these two Heinrich events, has been also reported for the western Iberian margin and adjacent landmasses during the last phase of HE1, 2 and 4 (Naughton et al., 2007). In western France, the drying trend during the middle and last phase of HE 4 and 5 would lead to reduce fen landscapes and develop bog-dominated mire. Despite the relative drying and fuel availability, which would favour the increase of fire regime, moisture conditions are assumed to remain important enough in western France to limit propagation of fire at the end of these events. Finally, the increase of fire regime during phase (b), initially attributed to drought, could be also the result of an increase of frequency of lighting storms during this period, which could occur during an atmospheric reorganisation between phases (a) and (c).

Heinrich event 6. During HE6, we observe the development of Picea forest associated to the expansion of Sphagnum and Pinus populations, along with Calluna and Cyperaceae species, typical of the present-day vegetation of the Boreal region. Interestingly, HE6 is marked by a different vegetation pattern compared to HE5 and 4 because of the relative high percentages of Pinus over the entire event and the two slight declines of this tree. However, fire regime is also characterised by a three-phase structure (Fig. 6c). The first low fire regime, phase (a), is associated with Pinus forest decline. Phase (b) is characterised by a first strong increase of fire regime (b1) followed by a "plateau" (b2) which coincides with a relatively well developed Pinus and Picea forest associated with the expansion of Sphagnum growing in humid environments and semi-desert plants growing apart in drier soils. The decrease of fire regime at the end of HE6 (c) is associated with the maximum expansion of Cyperaceae and surprisingly with Pinus 605 development.

606

As for HE4 and 5, the low fire regime during the first and last 607 phases may be related to low fuel content and relative moist 608 conditions limiting fire ignition and spread, respectively. The high 609 fire regime during (b1) may be explained by the development of 610 highly fire sensitive Boreal forest system (Bergeron et al., 2004) 611 associated with particularly dry climate as indicated by the strong 612 development of semi-desert vegetation.

613

Beyond climatic conditions favourable to Picea and Sphagnum 614 establishment during this period, high fire regime may have also 615 contributed to the resulting vegetation assemblage. Permafrost forms 616 in peatlands when mean annual temperature (MAT) is below $0^{\circ} \mathrm{C}$ and 617 becomes continuous when MAT is under $-6^{\circ} \mathrm{C}$. However, Camill 618 (2000) reports permafrost formation in Canadian boreal peatlands 619 related to dense Picea mariana trees and Sphagnum dry peat, 620 suggesting that cold temperature is not the unique factor involved 621 in permafrost formation. Alternation between Picea and Sphagnum 622 species in this region is triggered by fire. Picea trees diminish the solar 623 radiation at the surface soil and permafrost begins to form. Fire alters 624 Picea forest, the permafrost layer begins to melt and Sphagnum 625 develops due to unfrozen conditions. Over time, peat accumulates and 626 succession leads to favourable conditions for tree colonisation, which 627 may promote permafrost formation.

We assume as a working hypothesis that Picea and Sphagnum grew 629 together in western France during HE6. If we apply the present-day 630 model of P. mariana in North America to Picea in western Europe, at 631 longer time scale, the development of Picea-Sphagnum association 632 during (b1) concomitant with high fire regime suggests that 633 discontinuous permafrost occurred in western France during the 634 transition MIS 4/MIS 3. Moreover, forest fires of this period were 635 probably intense because the expansion of Sphagnum populations is 636 favoured by high-temperature forest fires (Greisman, 2006). Paleosols 637 testifying to short occurrence of permafrost have been detected in this 638 region during the youngest HE2 and 1 (Bertran et al., 2008). In 639 addition, evidence of permafrost formation during the HE6 time 640 interval is suggested from growth cessation of the Grotte de Villars's 641 speleothem located in southwestern France (Genty et al., 2003). 642

Fire regime stays at a high level during (b2) although this period is 643 contemporaneous with woody fuel decrease (Pinus and Picea popula- 644 tion decline) and increase in humidity (Pediastrum and Cyperaceae 645 increase). However, Pinus forest decline was smaller than in HE4 and 646 5. At the same time, Betula forest-steppe expanded at the expenses of 647 Picea (Fig. 5). This environmental succession might indicate thawing of 648 permafrost under the onset of particular warming and drying trend, 649 similar to that reported by Blyakharchuk and Sulerzhitsky (1999) for 650 the western Siberia forest zone during the Holocene. This particular 651 warming coincides with the start of obliquity increase (Fig. 5) and, 652 therefore, enhancement of seasonal contrast at northern latitudes 653 traced in our record by several well-marked GI characterised by the 654 highest development of Betula associated with summer SST above 655 $15^{\circ} \mathrm{C}$. This particular warming could explain the maintenance of strong 656 fire regime during (b2) likely resulted from particularly high summer 657 temperatures, despite of the decline of Pinus and Picea forest.

\section{Conclusion}

Microcharcoal and organic carbon analyses were applied to deep- 660 sea core MD04-2845 recovered in the Bay of Biscay, at $45^{\circ} \mathrm{N}$. Marine 661 productivity variability revealed by organic carbon content parallels 662 D-O climatic variability and is interpreted as a proxy of paleo-Navidad 663 current strength. This current appears to have been reinforced during 664 GI as the result of the prevailing negative NAO-like mode, and 665 inversely during GS. Both GI and GS climatic situations were marked 666 by dominant westerlies and microcharcoal concentration variation is 667 independent of changes in fluvial sedimentary input implying that D- 668 
O microcharcoal concentration variability reflects fire regime variation in western France during the last glacial period.

The highest fire regimes are observed during GI related to highfuel coniferous-mixed wooded vegetation. Decreasing fire regime is associated to fuel reduction in a steppe dominated environment during HE and the other GS. This fire regime pattern is similar to that observed in southwestern Iberia for the same time period and supports a regional climatic control of fire regime, through biomass changes, in western Europe.

Contrary to the continuous low fire regime during HE in southwestern Iberia (Daniau et al., 2007), a three-phase structure characterises fire regime within HE6, 5 and 4 in western France. The highest fire regime episode is bracketed by two low fire regime phases. The first low fire regime phase is related to the Pinus forest decline and wet conditions, while the fire increase is contemporaneous with an afforestation. The late fire decrease is, paradoxically, associated with the maintenance of substantial woody fuel and dryer conditions than those of the previous phase. We explain this late decrease as the result of a new phase of mire expansion. This would indicate climatic conditions sufficiently moist to limit fire spread. During HE6, the strong relationship between the highest fire regime and the expansion of Picea and Sphagnum communities would reflect the formation of discontinuous permafrost.

\section{Uncited reference}

\section{Komarek et al., 1973}

\section{Acknowledgments}

The work of A.-L. D. was supported by a BDI CNRS-région Aquitaine fellowship. This study was funded by the RESOLuTION (ESF-EUROCORES-EUROCLIMATE) and ARTEMIS projects. We gratefully acknowledge A. Landouar (LeicaMicrosystems) who provided useful assistance for LeicaQwin software language programming, B. Martin and E. Gonthier for advices and providing access to the slide polishing machine, $\mathrm{H}$. Etcheber, H. Derriennic and A. Coynel for their introduction to organic carbon analysis, O. Ther for carbonate measurements, and J. Giraudeau for looking at the coccoliths of some slides of core MD04-2845. We also thank W. Fletcher, F. Naughton, S. Toucanne, C. Lopez-Martinez, J.-M Jouanneau, P. Bertran, C. Garcia-Soto and S. Harrison for their valuable comments on different sections of this manuscript. We also thank 2 anonymous reviewers and Boris Vannière as well as the editor for their valuable comments. This is Bordeaux 1 University, UMR-CNRS 5805 EPOC Contribution no. 1726.

\section{References}

Allen, G.P., Castaing P. 1977. Carte de répartition des sédiments superficiels sur le plateau continental du Golfe de Gascogne. Bull. Inst. Géol. Bassin d'Aquitaine 21, $255-261$.

Andreae, M.O., Merlet, P., 2001. Emission of trace gases and aerosols from biomass burning. Global Biogeochemical Cycles 15, 955-966.

Bard, E., Rostek, F., Ménot-Combes, G., 2004. Radiocarbon calibration beyond 20,000 14C B.P. by means of planktonic foraminifera of the Iberian Margin. Quaternary Research 61, 204-214.

Batten, D.J., 1996. Palynofacies and palaeoenvironmental interpretation. In: Jansonius, J. McGregor, D.C. (Eds.), Palynology: Principles and Applications, 3. American Association of Stratigraphic Palynologists Foundation, pp. 1011-1064.

Beaufort, L., Heussner, S., 1999. Coccolithophorids on the continental slope of the Bay of Biscay - production, transport and contribution to mass fluxes. Deep-Sea Research II 46, 2147-2174.

Bergeron, Y., Gauthier, S., Flannigan, M., Kafka, V., 2004. Fire regimes at the transition between mixedwood and coniferous boreal forest in northwestern Quebec. Ecology 85, 1916-1932.

Bertran, P., Allenet, G., Gé, T., Naughton, F., Poirier, P., Sanchez Goni, M.F., 2008. Coversand and Pleistocene palaeosols in the Landes region, southwestern France. Journal of Quaternary Science, doi:10.1002/jqs.1220.

Blyakharchuk, T.A., Sulerzhitsky, L.D., 1999. Holocene vegetational and climatic changes in the forest zone of Western Siberia according to pollen records from the extrazonal palsa bog Bugristoye. The Holocene 9 (5), 621-628.
Boulter, M.C., 1994. An approach to a standard terminology for palynodebris. In: 734 Traverse, A. (Ed.), Sedimentation of Organic Particles. Cambridge University Press, 735 Cambridge, pp. 199-216.

Colonen, R.H.W., Tolonen, K., Tolonen, 1997. Holocene records of fire from 737 boreal and temperate zones of Europe. In: Clark, J.S., Cachier, H., Goldammer, H., 738 Stocks, B. (Eds.), Sediment Records of Biomass Burning and Global Change. 739 Springer-Verlag, Berlin, pp. 347-365.

Calvo, L., Tarrega, R., Luis, E., 2002. Regeneration patterns in a Calluna vulgaris heathland 741 in the Cantabrian mountains (NW Spain): effect of burning, cutting and ploughing. 742 Acta Oecologia 23, 81-90.

Camill, P., 2000. How much do local factors matter for predicting transient ecosytem 744 dynamics? Suggestions from permafrost formation in boreal peatlands. Global 745 Change Biology 6, 169-182.

Castaing, P., 1981. Le transfert à l'océan des suspensions estuariennes. Cas de la Gironde. 747 Doct. es Sciences thesis, Université Bordeaux1. 748

Colas, F., 2003. Circulation et dispersion lagrangiennes en Atlantique Nord-Est. Thesis, 749 Université de Bretagne Occidentale.

Combourieu Nebout, N., Turon, J.L., Zahn, R., Capotondi, L., Londeix, L., Pahnke, K., 2002. 751 Enhanced aridity and atmospheric high-pressure stability over the western 752 Mediterranean during the North Atlantic cold events of the past 50 ky. Geological 753 Society of America 30, 863-866.

Crutzen, P.J., Heidt, L.E., Krasnec, J.P., Pollock, W.H., Seiler, W., 1979. Biomass burning as a 755 source of atmospheric gases $\mathrm{CO}, \mathrm{H} 2, \mathrm{~N} 2 \mathrm{O}, \mathrm{NO}, \mathrm{CH} 3 \mathrm{Cl}$ and $\mathrm{COS}$. Nature 282, 253-256. 756

Daniau, A.L., Sánchez Goñi, M.F., Beaufort, L., Laggoun-Défarge, F., Loutre, M.F., Duprat, J., 757 2007. Dansgaard-Oeschger climatic variability revealed by fire emissions in 758 southwestern Iberia. Quaternary Science Reviews 26, 1369-1383. 759

Dupuis, H., Michel, D., Sottolichio, A., 2006. Wave climate evolution in the Bay of Biscay 760 over two decades. Journal of Marine Systems 63, 105-114. 761

Durrieu de Madron, X., Castaing, P., Nyffeler, F., Courp, T., 1999. Slope transport of 762 suspended particulate matter on the Aquitanian margin of the Bay of Biscay. Deep- 763 Sea Research II 46, 2003-2027.

Enache, M.D., Cumming, B.F., 2006. Tracking recorded fires using charcoal morphology 765 from the sedimentary sequence of Prosser Lake, British Columbia (Canada). 766 Quaternary Research 65, 282-292.

European Commission, 2001. Forest Fires In Southern Europe. Environment and Geo- 768 Information Unit report 1 (July). $\quad 769$

Etcheber, H., Relexans, J.C., Beliard, M., Weber, O., Buscail, R., Heussner, S., 1999. 770 Distribution and quality of sedimentary organic matter on the Aquitanian margin 771 (Bay of Biscay). Deep-Sea Research II 46, 2249-2288.

Flückiger, J., Blunier, T., Stauffer, B., Chappellaz, J., Spahni, R., Kawamura, K., Schwander, 773 J., Stocker, T.F., Dahl-Jensen, D., 2004. N2O and CH4 variations during the last glacial 774 epoch: insight into global processes. Global Biogeochemical Cycles 18.

Froidefond, J.M., Castaing, P., Jouanneau, J.M., 1996. Distribution of suspended matter in 776 a coastal upwelling area. Satellite data and in situ measurements. Journal of Marine 777 Systems 8, 91-105

Garcia-Soto, C., Pingree, R.D., Valdes, L., 2002. Navidad development in the southern Bay 779 of Biscay: climate change and swoddy structure from remote sensing and in situ 780 measurements. Journal of Geophysical Research 107 (C8), 3118.

Genty, D., Blamart, D., Ouahdi, R., Gilmour, M., Baker, A., Jouzel, J., Van-Exter, S., 2003. 782 Precise dating of Dansgaard-Oeschger climate oscillations in western Europe from 783 stalagmite data. Letters to Nature 421.

Greisman, A., 2006. Fire, forest and cultural landscape history during the last 785 11000 years in Småland - a case study at Stavsåkra. ESS Bulletin $4 . \quad 786$

Heaps, N.S. 1980. A mechanism for local upwelling along the European continental 787 slope. Oceanologica Acta 3, 449-454.

Hu, F.S., Brubaker, L.B., Gavin, D.G., Higuera, P.E., Lynch, J.A., Rupp, T.S., Tinner, W., 2006. 789 How climate and vegetation influence the fire regime of the Alaskan boreal biome: 790 the Holocene perspective. Mitigation and Adaptation Strategies for Global Change 791 11, 829-846C, doi:10.1007/s11027-005-9015-4.

Hughen, K.A., Baillie, M.G.L., Bard, E., Bayliss, A., Beck, J.W., Bertrand, C., Blackwell, P.G., 793 Buck, C.E., Burr, G., Cutler, K.B., Damon, P.E., Edwards, R.L, Fairbanks, R.G., Friedrich, 794 M., Guilderson, T.P., Kromer, B., McCormac, F.G., Manning, S., BronkRamsey, C., 795 Reimer, P.J., Reimer, R.W., Remmele, S., Southon, J.R., Stuiver, M., Talamo, S., Taylor, 796 F.W., van der Plicht, J., Weyhenmeyer, C.E., 2004. Marine04 marine radiocarbon age 797 calibration, 0-26 cal kyr BP. Radiocarbon 46, 1059-1086.

Jouanneau, J.M., Weber, O., Cremer, M., Castaing, P., 1999. Fine-grained sediment budget 799 on the continental margin of the Bay of Biscay. Deep-Sea Research II 46, 2205-2220. 800

Kennett, J.P., 1982. Marine Geology. Prentice-Hall, Englewood Cliffs, New Jersey. 801

Komarek, E.V., Komarek, B.B., Garlysle, C., 1973. The Ecology of Smoke Particulates and 802 Charcoal Residues from Forest and Grassland Fires: a Preliminary Atlas. Tall Timbers 803 Research Station, Tallahassee, Florida, p. 75 .

Koutsikopoulos, C., le Cann, B., 1996. Physical processes and hydrological structures 805 related to the Bay of Biscay anchovy. Scientia Marina 60 (2), 9-19. 806

Laitinen, J., Rehell, S., Oksanen, J., 2007. Community and species responses to water level 807 fluctuations with reference to soil layers in different habitats of mid-boreal mire 808 complexes. Plant Ecology, doi:10.1007/s11258-007-9271-3.

Laskar, J., Robutel, P., Joutel, F., Gastineau, M., Correia, A., Levrard, B., 2004. A long term 810 numerical solution for the insolation quantities of the Earth. Astronomy and 811 Astrophysics 428, 261-285.

Lazure, P., Jégou, A.M., 1998. 3D modelling of seasonal evolution of Loire and Gironde 813 plumes on Biscay Bay continental shelf. Oceanologica Acta 21,165-177. 814

Lericolais, G., Berné, S., Féniès, H., 2001. Seaward pinching out and internal stratigraphy of 815 the Gironde incised valley on the shelf (Bay of Biscay). Marine Geology 175, 183-197. 816

Linderholm, H.W., Leine, M., 2004. An Assessment of twentieth century tree-cover 817 changes on a southern Swedish peatland combining dendrochronology and aerial 818 photograph analysis. Wetlands 24, 357-363. 
Lobert, J.M., Scharffe, D.H., Hao, W.M., Crutzen, P.J., 1990. Importance of biomass burning in the atmospheric budgets of nitrogen-containing gases. Nature 346, 552-554.

Magri, D., 1994. Late-Quaternary changes of plant biomass as recorded by pollenstratigraphical data: a discussion of the problem at Valle di Castiglione, Italy. Review of Palaeobotany and Palynology 81, 313-325.

McNamara, J.P., Siegel, D.I., Glaser, P.H., Beck, R.M., 1992. Hydrogeologic controls on peatland development in the Malloryville Wetland, New York (USA). Journal of Hydrology 140, 279-296.

Moreno, A., Cacho, I., Canals, M., Prins, M., Sánchez Goñi, M.F., Grimalt, J.O., Weltje, G.J., 2002. Saharan dust transport and high-latitude glacial climate variability: the Alboran sea record. Quaternary Research 58, 318-328.

Mouillot, F., Rambal, S., Joffre, R., 2002. Simulating climate change impacts on fire frequency and vegetation dynamics in a Mediterranean-type ecosystem. Global Change Biology 8, 423-437.

Myers, P.G., Haines, K., Rohling, E.J., 1998. Modeling the paleocirculation of the Mediterranean: the last glacial maximum and the Holocene with emphasis on the formation of sapropel S1. Paleoceanography 13, 586-606.

Naughton, F., Sánchez Goñi, M.F., Desprat, S., Turon, J.-L., Duprat, J., Malaizé, B., Joli, C., Cortijo, E., Drago, T., Freitas, M.C., 2007. Present-day and past (last 25000 years) marine pollen signal off western Iberia. Marine Micropaleontology 62, 91-114.

Ni, J., Harrison, S.P., Prentice, I.C., Kutzbach, J.E., Sitch, S., 2006. Impact of climate variability on present and Holocene vegetation: a model-based study. Ecological Modelling 191, 469-486.

Noël, H., 2001. Caractérisation et calibration des flux organiques sédimentaires dérivant du bassin versant et de la production aquatique (Annecy, le Petit lac). Rôles respectifs de l'Homme et du climat sur l'évolution des flux organiques au cours des 6000 dernières années. Ph. D. Thesis, Sciences de l'Univers, Pétrographie et Géochimie Organiques, Université d'Orléans, Orléans, France.

Ozenda, P., 1982. Les Végétaux Dans La Biosphère. Paris, Doin, p. 431.

Pailler, D., Bard, E., 2002. High frequency palaeoceanographic changes during the past $140,000 \mathrm{yr}$ recorded by the organic matter in sediments of the Iberian margin. Palaeogeography, Palaeoclimatology, Palaeoecology 181, 431-452.

Petit, J.R., Jouzel, J., Raynaud, D., Barkov, N.I., Barnola, J.-M., Basile, I., Bender, M., Chappellaz, J., Davis, M., Delaygue, G., Delmotte, M., Kotlyakov, V.M., Legrand, M., Lipenkov, V.Y., Lorius, C., Pepin, L., Ritz, C., Saltzman, E., Stievenard, M., 1999. Climate and atmospheric history of the past 420,000 years from the Vostok ice core, Antarctica. Nature 399, 429-436.

Polunin, O., Walters, M., 1985. A Guide to the Vegetation of Britain and Europe. Oxford University Press, New York.

Power, M.J., Marlon, J., Ortiz, N., Bartlein, P.J., Harrison, S.P., Mayle, F.E., Ballouche, A., Bradshaw, R.H.W., Carcaillet, C. Cordova, C. Mooney, S., Moreno, P.I. Prentice, I.C., Thonicke, K., Tinner, W., Whitlock, C., Zhang, Y., Zhao, Y., Ali, A.A., Anderson, R.S., Beer, R., Behling, H., Briles, C., Brown, K.J., Brunelle, A., Bush, M., Camill, P., Chu, G.Q., Clark, J., Colombaroli, D., Connor, S., Daniau, A.-L., Daniels, M., Dodson, J., Doughty, E., Edwards, M.E., Finsinger, W., Foster, D., Frechette, J., Gaillard, M.J., Gavin, D.G. Gobet, E., Haberle, S., Hallett, D.J., Higuera, P., Hope, G., Horn, S., Inoue, J., Kaltenreider, P., Kennedy, L., Kong, Z.C., Larsen, C., Long, C.J., Lynch, J., Lynch, E.A. McGlone, M., Meeks, S., Mensing, S., Meyer, G., Minckley, T., Mohr, J., Nelson, D.M., New, J., Newnham, R., Noti, R., Oswald, W., Pierce, J., Richard, P.J.H., Rowe, C., Sánchez Goñi, M.F., Shuman, B.J., Takahara, H., Toney, J., Turney, C., Urrego-Sanchez, D.H., Umbanhowar, C., Vandergoes, M., Vanniere, B., Vescovi, E., Walsh, M., Wang, X., Williams, N., Wilmshurst, J., Zhang, J.H., 2007. Changes in fire regimes since the Last Glacial Maximum: an assessment based on a global synthesis and analysis of charcoal data. Climate Dynamics, doi:10.1007/s00382-007-0334-x.

Puillat, I., Lazure, P., Jégou, A.M., Lampert, L., Miller, P.I., 2004. Hydrographical variability on the French continental shelf in the Bay of Biscay, during the 1990s. Continental Shelf Research 24, 1143-1163.
Rixen, M., Beckers, J.-M., Levitus, S., Antonov, J., Boyer, T., Maillard, C., Fichaut, M., 879 Balopoulos, E., Iona, S., Dooley, H., Garcia, M.J., Manca, B., A., G., Manzella, G., 880 Mikhailov, N., Pinardi, N., Zavatarelli, M., the Medar Consortium, 2005. The Western 881 Mediterranean Deep Water: a proxy for climate change. Geophysical Research 882 Letters 32 NIL 47-NIL 50.

Rochefort, L., Campeau, S., Bugnon, J.-L., 2002. Does prolonged flooding prevent or 884 enhance regeneration and growth of Sphagnum? Aquatic Botany 74, 327-341. 885

Ruch, P., Mirmand, M., Jouanneau, J.-M., Latouche, C., 1993. Sediment budget and 886 transfer of suspended sediment from the Gironde estuary to Cap Ferret Canyon. 887 Marine Geology 111, 109-119.

Sánchez Goñi, M.F., Cacho, I., Turon, J.-L., Guiot, J., Sierro, F.J., Peypouquet, J.P., Grimalt, J.O., 889 Shackleton, N.J., 2002. Synchroneity between marine and terrestrial responses to 890 millennial scale climatic variability during the last glacial period in the Mediterranean 891 region. Climate Dynamics 19, 95-105.

Sánchez Goñi, M.F., Landais, A., Fletcher, W., Naughton, F., Desprat, S., Duprat, J., 2008, 893 Contrasting impacts of Dansgaard-Oeschger events over a western European 894 latitudinal transect modulated by orbital parameters. Quaternary Science Reviews 895 27, 1136-1151.

Serryn, P., 1994. Atlas Bordas Géographique. Hölzel, Paris.

Shackleton, N.J., et al., 2000. MD95-2042 Oxygen and Carbon Isotope Data. IGBP PAGES/ 898 World Data Center A for Paleoclimatology Data Contribution Series \#2000-066. 899 NOAA/NGDC Paleoclimatology Program. Boulder CO, USA.

Shackleton, N.J., Fairbanks, R.G., Chiu, T.-C., Parrenin, F., 2004. Absolute calibration of the 901 Greenland time scale: implications for Antarctic time scales and for $\Delta 14 \mathrm{C} .902$ Quaternary Science Reviews 23, 1513-1522. 903

Stuiver, M. Reimer, PJ. 1993. Extended ${ }^{14} \mathrm{C}$ database and revised CALIB radiocarbon 904 calibration program. Radiocarbon 35, 215-230. 905

Stuiver, M., Reimer, P.J., Reimer, R.W., 2005. CALIB 5.0. (www program and 906 documentation).

Théry-Parisot, I., 1998. Economie du combustible et Paléoécologie en contexte glaciaire 908 et périglaciaire, Paléolithique moyen et supérieur du sud de la France. Anthraco- 909 logie, Experimentation, Taphonomie. Thesis, Université de Paris I Panthéon- 910

Sorbonne. 911

Thonicke, K., Prentice, C.I., Hewitt, C., 2005. Modeling glacial-interglacial changes in 912 global fire regimes and trace gas emissions. Global Biogeochemical Cycles 19, 913 GB3008, doi:10.1029/2004GB002278.

Toucanne, S., Mulder, T., Schönfeld, J., Hanquiez, V., Gonthier, E., Duprat, J., Cremer, M., 915 Zaragosi, S., 2007. Contourites of the Gulf of Cadiz: a high-resolution record of the 916 paleocirculation of the Mediterranean outflow water during the last 50,000 years. 917 Palaeogeography, Palaeoclimatology, Palaeoecology 246, 354-366.

Trigo, R.M., Osborn, T.J., Corte-Real, J.M., 2002. The North Atlantic Oscillation influence 919 on Europe: climate impacts and associated physical mechanisms. Climate Research 920 20, 9-17.

Turon, J.-L., 1984. Le palynoplancton dans l'environnement actuel de l'Atlantique nord- 922 oriental. Evolution climatique et hydrologique depuis le dernier maximum 923 glaciaire. Mémoires de l'Institut de Géologie du bassin d'Aquitaine (17) Université 924 de Bordeaux I, Bordeaux.

van Aardenne, J.A., Dentener, F.J., Oliver, J.G.J., Klein Goldewijk, C.G.M., Lelieveld, J., 2001. 926 A 1 X 1 resolution data set of historical anthropogenic trace gas emissions for the 927 period 1890-1990. Global Biogeochemical Cycles 15, 909-928.

Van der Werf, G.R., Randerson, J.T., Collatz, G.J., Giglio, L., Kasibhatla, S., Arellano, J.A.F., 929 Olsen, S.C., Kasischke, E.S., 2004. Continental-scale partitioning of fire emissions 930 during the 1997 to 2001 El Nino/La Nina Period. Science 303, 73-76.

Van Huissteden, J. Gibbard, P. Briant, R.M. 2001. Periglacial fluvial systems in 932 northwest Europe during oxygen isotope stages 4 and 3. Quaternary International 933 79, 75-88.

Voelker, A.H.L., Lebreiro, S.M., Schönfeld, J., Cacho, I., Erlenkeuser, H., Abrantes, F., 2006. 935 Mediterranean outflow strengthening during northern hemisphere coolings: a salt 936 source for the glacial Atlantic? Earth and Planetary Science Letters 245, 39-55. 937 